treatment for the patient, is left entirely in the hands of the clinician in this system.

What the computing system does is to help the clinician in an area where previous studies (de Dombal et al., 1972a) have shown him to be relatively weak-namely, in the statistical analysis of large volumes of data. In such a case the clinician merely uses the computer to augment his own capabilities and judgement; and indeed there is ample precedent for this. To take one obvious example, the clinician often uses a stethoscope to algment his ability to hear sounds emanating from within a body cavity. Sometimes the clinical picture is clear-cut; in this instance the clinician merely uses his stethoscope to confirm his previous assessment of the patient. Sometimes the results which the clinician obtains from the use of the stethoscope are difficult to interpret or are at odds with what the clinician "feels" about the case-in such circumstances the clinician is at liberty to disregard the evidence from his "machine." But in a proportion of cases the evidence the clinician obtains will alter his impression of the case sufficiently to make him seek additional evidence and this in turn will lead him to the "correct" diagnosis.

This is precisely the type of computer usage which we have envisaged and tried to embody in the present system. No one speaks of a stethoscope making a diagnosis; and it seems to us meaningless to speak of the computer in terms which imply that this sort of machine system usurps the clinician's traditional role, even if, when the computer indicates its probabilities, we speak of the most likely complaint as being the "computer's diagnosis."

\section{LEVEL OF COMPUTING EXPERTISE REQUIRED}

Here the problem is much simpler. We have been impressed in earlier studies by the fact that clinicians are relatively reluctant and ineffectual users of any computing system (see de Dombal et al., 1971a). The answer we have adopted is twofold. Firstly, we have instituted a three-tier system of computer training at undergraduate level, evidenced inter alia by the work referred to earlier. As regards the present we have instituted a computing system in which the knowledge and expertise required from the clinician is precisely nil. The clinician has merely to fill out a provided form, in English, and then subsequently to read a computer printout (again in English) as shown in Figs. 7, 8, and 9. The only "computer appreciation" necessary on the part of the clinician is an awareness that the computer is not infallible and that its "diagnosis" is merely an indication of probabilities on the data fed into it. Nothing else is needed, and certainly no programming or mathematical expertise is necessary for the clinician who elects to use the system.

It must be apparent from the foregoing that we owe a considerable debt of gratitude to many of our colleagues. It is a pleasure to thank Professor K. Smith, of the Department of Computational Science, and Professor M. Wells, of the Electronic Computing Laboratory, for their support and encouragement during the course of these studies. We thank also the members of their staffs who have given us much advice, comment, and helpful criticism, and without whom it would have been impossible to carry out 2,000 diagnoses in less than one year. Finally, three of us (J.C.H., A.P.M., and D.J.L.) were aided by a grant from the Medical Research Council, which we also acknowledge with gratitude.

Requests for reprints should be sent to Mr. F. T. de Dombal, University Department of Surgery, General Infirmary, Leeds LS1 3EX.

\section{References} de Dombal, F. T., Hartley, J. R., and Sleeman, D. H. (1969a). Lancet, 1, 145.
de Dombal, F. T., Hartley, J. R., and Sleeman, D. H. (1969b). British de Dombal, F. T., Hartley, J.

Fournal of Surgery, 56, 754.
de Dombal, F. T., Horrocks, Jane C., Staniland, J. R., and Gill, P. W. (1971a). British Medical fournal, 2, 575.

de Dombal, F. T., Horrocks, Jane C., Staniland, J. R., and Guillou, P. J. (1971b). British Medical fournal, 2, 578.

de Dombal, F. T., Horrocks, Jane C., Staniland, J. R., and Guillou, P. J. (1971c). Proceedings of the Royal Society of Medicine, 64, 978.

de Dombal, F. T., Horrocks, Jane C., Staniland, J. R., and Guillou, P. J. (1972a). Methods of Information in Medicine, 11, 82.

de Dombal, F. T., Leaper, D. J., and Gill, P. W. (1972b). Observer variation in recording the diagnostic process. In preparation.

de Dombal, F. T., Leaper, D. J., Staniland, J. R., McCann, A. P., and Horrocks, Jane C. (1972c). In press.

Edwards, W. (1966). Transactions on Human Factors in Electronics (HFE), 7,1 .

Graham, N. G., de Dombal, F. T., and Goligher, J. C. (1971). British Medical fournal, 2, 746 .

Lusted, L. B. (1968). In Introduction to Medical Decision-making, p. 3. Springfield, Illinois, Thomas.

Staniland, J. R., Ditchburn, Janet, and de Dombal, F. T. (1972). British Medical fournal. In press.

Wells, M., Holdsworth, D., McCann, A. P. (1971). Computer fournal, 14, 22.

\title{
Computer-aided Diagnosis of Acute Abdominal Pain
}

\section{F. T. de DOMBAL, D. J. LEAPER, J. R. STANILAND, A. P. MCCANN, JANE C. HORROCKS}

British Medical Fournal, 1972, 2, 9-13

\section{Summary}

This paper reports a controlled prospective unselected real-time comparison of human and computer-aided diagnosis in a series of 304 patients suffering from abdominal pain of acute onset.

The computing system's overall diagnostic accuracy $(91.8 \%)$ was significantly higher than that of the most

Department of Surgery and Computational Science and the Electronic Computing Laboratory, University of Leeds

F. T. de DOMBAL, M.D., F.R.C.s., Reader in Clinical Information Science D. J. LEAPER, M.B., CH.B., Research Assistant, University Department of Surgery

J. R. STANILAND, Formerly Assistant in Surgical Research (Present address: Trinity Hall, University of Cambridge)

A. P. McCANN, M.SC., PH.D., Lecturer in Computational Science

JANE C. HORROCKS, Programmer, University Department of Surgery senior member of the clinical team to see each case $(79.6 \%)$. It is suggested as a result of these studies that the provision of such a system to aid the clinician is both feasible in a real-time clinical setting, and likely to be of practical value, albeit in a small percentage of cases.

\section{Introduction}

We have already described our general operational experience with an adaptable real-time computer-aided diagnostic system and discussed some of the problems inherent in its implementation (Horrocks et al., 1972). But some important questions remain unanswered in the previous discussion. Chiefly these are two: do clinicians actually need such a system ? and can it offer any measurable advantage in terms of diagnostic accuracy and reliability over more conventional methods ? Such questions can be answered only at the bedside, in a routine clinical environment, by undertaking a controlled prospective trial in which the diagnostic performance of the unaided clinician is compared 
with that of the system already described. If in these circumstances the system offers no measurable advantages over the conventional situation, then whatever its possible merits it must be accounted of little practical value. In this paper we present the results of such an assessment carried out over a period of 11 months in a busy clinical unit.

\section{Conduct of Investigation}

In this investigation we studied patients presenting with acute abdominal pain to the professorial surgical unit in the General Infirmary at Leeds. The study was begun on 1 January 1971 and terminated on 1 December 1971. The computer-aided system used has been described in detail (Horrocks et al., 1972). We attempted to deal with all cases admitted to the wards under the care of the professorial surgical unit, criteria for admission to the survey being: (1) the patient's presenting complaint was abdominal pain, (2) this pain had arisen within one week of admission, (3) the admission was an emergency procedure via the receiving room, (4) the patient was not already on the series (ruling out by previous definition any repeated admissions), (5) the patient was capable of giving a medical history (ruling out a baby aged 2 weeks, and one further unconscious patient), and (6) a diagnosis was eventually made (excluding one further patient in whom the diagnosis of acute appendicitis remained in doubt even after operation). A total of 304 patients were accepted into the survey by these selection criteria.

We studied the patients at the same time as the clinical team, noting the diagnosis on admission (where one was available), the house surgeon's diagnosis, and that of any more senior members of the team who saw the patient. Details of the case history were entered into the computing system and a "realtime" diagnosis was produced as described. (This was not made available to the clinical team at that point in time, since to do so might have biased their handling of the case.) The patient was then taken to the theatre, if appropriate, and an operative diagnosis rapidly became available. This too was noted and filed for later analysis.

Two points are worthy of comment. First, our choice of the "acute abdomen" was a deliberate one, since such an area of diagnosis has several advantages. It is a common clinical dilemma ( 304 cases presented in less than a year). The number of possible disorders is relatively small (as evidenced by the low percentage of "unclassifiable" patients). The clinical diagnosis is usually made on the basis of a patient's symptoms and physical signs rather than on any lengthy biochemical tests; and the final diagnosis is usually made at operation. We are not unaware of the problems inherent in the term "diagnosis" but we feel that selection of the "acute abdomen" for study at least minimizes them.

Second, we elected to enter into the computer the data which the registrar obtained at the time when he first saw the case. This is important since clinical data change, and a case which may be puzzling in the extreme when first seen may become "obvious" by the next morning. We entered the initial data into the computer since we did not wish any advantage shown to be obscured by this kind of temporal problem. (In practice this sometimes worked to the computer's disadvantage, but we were prepared to accept this penalty.) It is, however, important to note that we were comparing (a) the registrar's initial diagnosis with $(b)$ the computer's probabilities based on the same data. We were not comparing our own diagnostic ability with that of the clinical team, for that comparison we felt to be irrelevant.

\section{Results}

\section{OVERALL FINAL DIAGNOSES}

Table I shows the final diagnosis made in each of the 304 cases. Most of the disease categories are self-explanatory, and most
TABLE I-Final Diagnoses made in 304 Patients

\begin{tabular}{|c|c|c|c|c|c|}
\hline & & & & No. of Cases & $\%$ \\
\hline $\begin{array}{l}\text { "Non-specific abdominal pain" } \\
\text { Appendicitis } \ldots\end{array} \ldots$ & $\begin{array}{l}\ldots \\
\ldots \\
\cdots \\
\cdots \\
\cdots \\
\cdots\end{array}$ & $\begin{array}{l}\ldots \\
\because \\
\cdots \\
\because \\
\cdots \\
\cdots\end{array}$ & $\begin{array}{l}\cdots \\
\cdots \\
\cdots \\
\cdots \\
\cdots\end{array}$ & $\begin{array}{r}149 \\
85 \\
26 \\
17 \\
8 \\
7 \\
4 \\
8\end{array}$ & $\begin{array}{r}49 \cdot 0 \\
28 \cdot 0 \\
8 \cdot 6 \\
5 \cdot 6 \\
2 \cdot 6 \\
2 \cdot 3 \\
1 \cdot 3 \\
2 \cdot 6\end{array}$ \\
\hline
\end{tabular}

of the diagnoses were made at operation, undertaken either at the time of the acute episode or shortly afterwards. Occasionally, other biochemical evidence was accepted by the clinical team, such as the finding of a serum amylase raised above a level of 1,000 Somogyi units, which was accepted as evidence of pancreatitis. Non-specific abdominal pain (N.S. pain) was the term applied when no apparent cause was found for the patient's pain; either they settled down in the short term, were discharged home and were reviewed later, or they underwent a negative laparotomy. In this category we have also included a few patients with conditions which did not warrant any surgical treatment, such as urinary tract infection.

The most striking feature of Table I, however, is the finding that less than $3 \%$ of the admissions did not fall into one or other of the categories listed. This confirms our earlier impression that patients with acute abdominal pain form an admirable subgroup for study, since over $95 \%$ of them can be collected together under a small list of seven disease headings.

\section{DIAGNOSIS ON ADMISSION}

It was not our purpose to study this aspect of the patient's medical care, and in many ways to do so would be unfair to the admitting staff. They saw cases at an earlier stage than ourselves, and many patients were sent home, so that they never came to us at all. Thus we cannot begin to measure their overall reliability or accuracy of diagnosis. But it is worth remarking that in only $44.8 \%$ of the cases we studied was the admitting diagnosis identical with the final operative diagnosis. This merely re-emphasizes that a considerable diagnostic problem remains when the patient enters the ward.

\section{DIAGNOSES OF ALL CLINICIANS}

Most of the cases were seen by at least two clinicians-the house surgeon and the registrar. Occasionally a senior registrar or consultant was called in to see the case, and the total number of clinical diagnoses made was 858. (We accepted only one primary diagnosis from each clinician, although we were forced to introduce an "unknown" category in this respect.) Of these 858 diagnoses of clinicians some 563 were later substantiated (Table II), a diagnostic accuracy of $65.6 \%$. This in

TABLE II-Clinicians' Diagnoses in a Series of 304 Patients with Acute Abdominal Pain

\begin{tabular}{|c|c|c|c|c|c|c|c|c|c|c|}
\hline & & & \multicolumn{8}{|c|}{ Clinicians' Diagnoses } \\
\hline & & & Appx. & Divert. & $\begin{array}{l}\text { Perf. } \\
\text { D.U. } \\
\end{array}$ & $\begin{array}{l}\text { N.S. } \\
\text { Pain }\end{array}$ & $\begin{array}{c}\text { Chole- } \\
\text { cyst. }\end{array}$ & $\begin{array}{l}\text { S.B. } \\
\text { Obst. }\end{array}$ & $\begin{array}{l}\text { Pan- } \\
\text { creat. }\end{array}$ & $\begin{array}{l}? ! \\
\text { Other }\end{array}$ \\
\hline \multirow{8}{*}{ 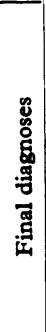 } & Appx. & . & 221 & 2 & 一 & 13 & - & 1 & 一 & 8 \\
\hline & Divert. & $\ldots$ & - & 3 & - & 3 & - & 3 & 一 & 3 \\
\hline & Perf. D.U. & $\ldots$ & 3 & - & 12 & - & - & - & 1 & 2 \\
\hline & N.S. Pain & $\ldots$ & 144 & - & 6 & 233 & 4 & 7 & 3 & 22 \\
\hline & Cholecyst & $\ldots$ & 7 & - & 3 & 4 & 48 & 2 & 7 & 6 \\
\hline & S.B. Obst. & $\ldots$ & 1 & 一 & 一 & - & - & 39 & - & 2 \\
\hline & Pancreat. & $\ldots$ & - & 2 & 3 & - & 7 & 1 & 5 & 3 \\
\hline & Other & .. & 9 & 1 & & 1 & & 4 & & 9* \\
\hline
\end{tabular}

- 2 correct, 7 wrong. 
turn merely serves to re-emphasize that the "acute abdomen" is an area of considerable diagnostic difficulty.

\section{HOUSE SURGEONS}

One of our interests was in looking at well-defined groups of clinicians, such as house surgeons working with the clinical team during 1971, though it should be noted that the house surgeons did not see every case. On occasion the house surgeon was on leave, and on occasion the registrar would be called direct to see the patient. In such circumstances the registrar would occasionally help the hard-pressed house surgeon by writing up the case himself, and arranging theatre procedures. Thus a house surgeon's diagncsis was available to us in only 266 of the 304 cases. Subsequent analysis showed the overall diagnostic accuracy of the house surgeon to be $72 \cdot 2 \%$.

\section{REGISTRARS}

It will be recalled that the clinical data entered into the computer were those obtained by the registrar when he first saw the case. An interesting comparison may therefore be made between the computer's analysis of the probabilities and the diagnoses made by these clinicians of registrar level. The latter findings are set out in Table III. The overall diagnostic accuracy at registrar level was $77 \cdot 0 \%$. TABLE III-Analysis of Diagnoses made by Clinicians of Registrar Grade in 304
Patients. (Occasionally Two Registrars saw the Case Simultaneously-Both Diagnoses then being Entered)

\begin{tabular}{|c|c|c|c|c|c|c|c|c|c|}
\hline & & Appx. & Divert. & $\begin{array}{c}\text { Perf. } \\
\text { D.U. }\end{array}$ & $\begin{array}{c}\text { N.S. } \\
\text { Pain }\end{array}$ & $\begin{array}{c}\text { Chole- } \\
\text { cyst. }\end{array}$ & $\begin{array}{c}\text { S.B. } \\
\text { Obst. }\end{array}$ & $\begin{array}{c}\text { Pan- } \\
\text { creat. }\end{array}$ & $\begin{array}{c}\text { ? } \\
\text { Other }\end{array}$ \\
\hline Appx. &.. & 76 & 1 & - & 7 & - & - & - & 3 \\
\hline Divert. &. & 1 & 3 & - & 1 & - & - & - & 1 \\
\hline Perf. D.U. .. & 1 & 1 & 5 & - & - & - & - & 1 \\
\hline N.S. Pain &.. & 27 & - & 1 & 117 & 2 & - & 1 & 1 \\
\hline Cholecyst. .. & 1 & - & - & - & 22 & 1 & 5 & 2 \\
\hline S.B. Obst. .. & - & - & - & 1 & - & 17 & 1 & - \\
\hline Pancreat. &. & - & 1 & 1 & - & 1 & - & 7 & - \\
\hline Other & $\ldots$ & 5 & 1 & - & - & - & 1 & - & $5 *$ \\
\hline
\end{tabular}

*1 correct, 4 wrong.

\section{SENIOR CLINICIANS}

One established principle of biomedical research is to compare any innovation with the best current available management, and we therefore analysed separately the diagnosis in each instance

TABLE IV-Diagnoses made by Senior Clinician in Charge of Case-304 Patients with Acute Abdominal Pain

\begin{tabular}{|c|c|c|c|c|c|c|c|c|c|c|}
\hline & & & \multicolumn{8}{|c|}{ Senior Clinical Diagnoses } \\
\hline & & & Appx. & Divert. & $\begin{array}{l}\text { Perf. } \\
\text { D.U. }\end{array}$ & $\begin{array}{l}\text { N.S. } \\
\text { Pain }\end{array}$ & $\begin{array}{l}\text { Chole- } \\
\text { cyst. }\end{array}$ & S.B. & $\begin{array}{l}\text { Pan- } \\
\text { creat. }\end{array}$ & $\begin{array}{l}? ! \\
\text { Other }\end{array}$ \\
\hline \multirow{8}{*}{ 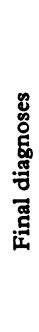 } & Appx. & $\ldots$ & 75 & 1 & - & 6 & 一 & 一 & 一 & 3 \\
\hline & Divert. & . & - & 2 & - & 1 & - & 一 & - & 1 \\
\hline & Perf. D.U. & . & 1 & 一 & 5 & 一 & - & 一 & 一 & 1 \\
\hline & N.S. Pain & $\ldots$ & 27 & - & 1 & 117 & 2 & 一 & 1 & 1 \\
\hline & Cholecyst. & & - & - & 一 & 一 & 20 & 1 & 3 & 2 \\
\hline & S.B. Obst. & $\cdots$ & - & 一 & 一 & - & 一 & 17 & - & - \\
\hline & Pancreat. & .. & 一 & 1 & 1 & - & 1 & 一 & 5 & 二 \\
\hline & Other & 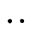 & 3 & 1 & - & 1 & 一 & 1 & 一 & 2* \\
\hline
\end{tabular}

*1 correct, 1 wrong. of the most senior clinician who saw the case. There were (naturally) some 304 such diagnoses, of which 242 were ultimately "correct" (Table IV), giving an overall correct diagnosis rate for the clinical team as at present constituted of $79 \cdot 6 \%$.

\section{COMPUTING SYSTEM}

We also noted for each patient the computer's primary "diagnosis"- that is to say, the disease category to which the computer allotted the highest probability. The results are shown in Table V.

TABLE v-Computer Prediction versus Final Diagnoses in a Series of 304 Patients with Acute Abdominal Pain

\begin{tabular}{|c|c|c|c|c|c|c|c|c|c|c|}
\hline & & & & \multicolumn{7}{|c|}{ Computer Prediction } \\
\hline & & & & Appx. & Divert. & $\begin{array}{l}\text { Perf. } \\
\text { D.U. }\end{array}$ & $\begin{array}{l}\text { N.S. } \\
\text { Pain }\end{array}$ & $\begin{array}{c}\text { Chole- } \\
\text { cyst. }\end{array}$ & $\begin{array}{l}\text { S.B. } \\
\text { Obst. }\end{array}$ & $\begin{array}{l}\text { Pan- } \\
\text { creat. }\end{array}$ \\
\hline \multirow{8}{*}{ 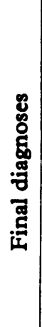 } & Appx. & . & . & 84 & 1 & 一 & - & - & - & - \\
\hline & Divert. & . & . & - & 4 & - & - & - & - & - \\
\hline & Perf. D.U. & . & . & - & - & 7 & - & - & - & - \\
\hline & N.S. Pain & . & . & 6 & - & 1 & 136 & 1 & - & 3 \\
\hline & Cholecyst. & . & $\ldots$ & - & - & - & - & 26 & - & - \\
\hline & S.B. Obst. & $\ldots$ & $\cdots$ & - & - & - & - & - & 16 & 1 \\
\hline & Pancreat. & . & . & - & 1 & 1 & - & - & - & 6 \\
\hline & Other* & . & . & 3 & 3 & - & 1 & 1 & - & - \\
\hline
\end{tabular}

*Computer by definition unable to diagnose these cases. Also two cases where system "failed-safe"- that is, computer unable to make diagnostic attempt since system.

The computer's "diagnosis," as indicated by the probabilities on the given data, matched the eventual diagnosis in some 279 instances. This represents a "diagnostic accuracy" for the computing system of $91.8 \%$. The remaining 25 cases were misclassified by the system. In two of these cases the patient's data could not be entered into the system, since the clinicians were unable to produce an agreed version for entry. In these two instances no diagnosis could be made, and the system "failed safe." The cases were, however, listed as failures of the system, as were an additional eight patients who presented with miscellaneous conditions warranting urgent surgical intervention such as bleeding ovarian cysts, perforated carcinoma of the rectosigmoid, and ruptured subcapsular haematoma of the spleen.

What one regards as the system's "accuracy" is therefore a matter of conjecture. It is possible to state that the system differentiated between the group of diseases in the "database" of information with an accuracy of $94.9 \%$, since there were 294 such cases and 279 were correctly diagnosed. On the other hand, this is an unrealistic estimate, since in routine clinical practice one can never be sure that patients admitted will of necessity be confined to one specific subset of diseases. The figure of $91.8 \%$ is undoubtedly an assessment which more accurately reflects the computer-assisted system's potential in a practical setting.

\section{Comparison between Clinicians and Computer}

How does one begin to assess a diagnostic system-either human or computer-aided? This is a matter of some controversy, and we have deliberately chosen to make some extremely simple comparisons between the humans and the computersystem-comparisons which related to the potential use of such an automated system in a future clinical environment. Thus we have chosen to ignore diagnoses made in the receiving room and by the house staff, since in most clinical environments a registrar's opinion is available, and since in any event we entered data elicited by the registrar into the computer. In comparing 
the computing system with the most senior clinician who saw the case we have undoubtedly biased the results against the computer-partly on account of the time factor already mentioned. Often some hours elapsed between the time data were entered into the computer and the time the case was seen by a senior clinician, and in this time the physical signs changed in such a way as to clarify the diagnosis. Nevertheless we retained this comparison, since we wished to compare the computing system with clinical practice as it is in real life.

With this as background we considered three facets of diagnostic performance-namely, accuracy, reliability, and certainty of diagnosis.

\section{ACCURACY OF DIAGNOSIS}

If a patient with disease " $A$ " is admitted how likely is this to be correctly diagnosed before operation? The results of this comparison are shown in Fig. 1. In six out of the eight disease

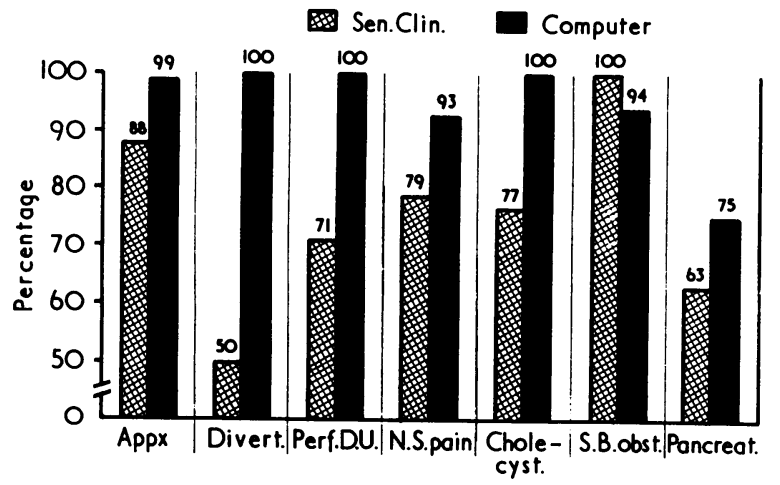

FIG. 1-Accuracy of diagnosis in 304 patients: comparison of computer prediction versus diagnosis of most senior clinician to see the case.

categories, the computer's classification proved eventually more likely to be accurate than that of the clinician in charge of the case.

Particularly gratifying from our own point of view was the finding that the computer system accurately classified 84 out of a possible 85 patients with acute appendicitis, and also that all seven patients with perforated duodenal ulcer were accurately classified by the system. This contrasts with the clinicians' performance, where only 75 diagnoses of appendicitis were made, and six patients were originally classified as non-specific abdominal puin. These six patients came to laparotomy only after what we arbitrarily defined as a significant delay (over eight hours). Overall the computer's "error" rate (25 cases out of $304,8.2 \%$ ) compared favourably with that of the clinician in charge of each case ( 62 cases, $20.4 \%$ ), and this difference in error rates is statistically significant $\left(x^{2}=15 \cdot 73\right.$, D.F. $=1$, $P=0.0001$.

\section{RELIABILITY OF DIAGNOSIS}

But accuracy of diagnosis alone is not enough. A further query concerns the reliability of the system and the clinicians. If the system or the clinician in charge made a diagnosis, how likely was this to be right? The answers to this somewhat different question are set out for this series in Fig. 2.

Here the computer proved more reliable than the clinician in charge in respect of every disease category investigated. We were particularly gratified to note that where the computer classified a patient into the non-specific abdominal pain category-implying perhaps a less serious view of the patient's illness-on no fewer than 136 out of 137 occasions this proved to be justified. This again implies an element of safety in the classification system which was not matched by the clinicians.

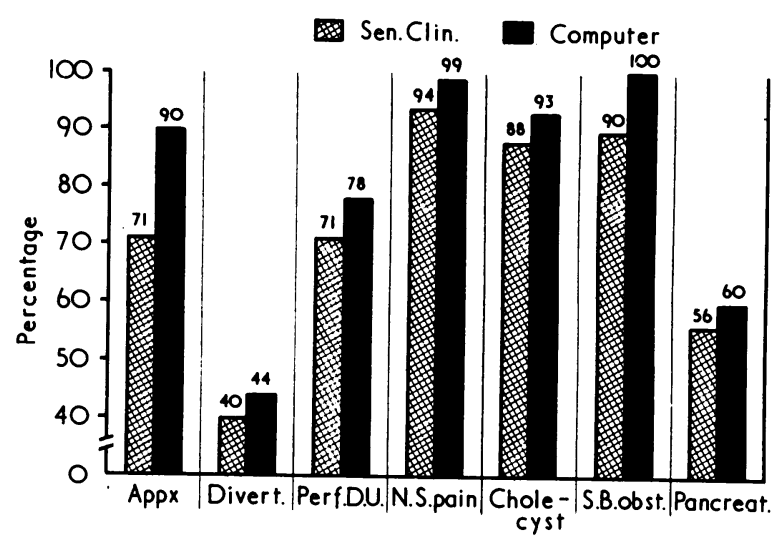

FIG. 2-Reliability of diagnosis in 304 patients; same comparison as in Fig. 1.

Moreover, although the computer erroneously classified six non-specific abdominal pain patients into the "appendicitis" category, the corresponding figure for the clinical team was no fewer than 27 patients.

Thus combining the elements of accuracy and reliability and taking the "appendicitis versus non-specific abdominal pain" diagnostic problem alone the situation was as follows: the computer's probabilities assigned correctly 84 patients with appendicitis, and 136 patients with non-specific abdominal pain. Had we slavishly followed the computer's predictions, six negative laparotomies would have been performed, but in no case of appendicitis would surgery have been delayed. What actually happened was rather different. Twenty-odd negative laparotomies were performed, and six cases of appendicitis were "observed" for over eight hours before the decision to operate was taken. This represents in our view a handy margin of performance in favour of the computer-aided system.

\section{CERTAINTY OF DIAGNOSIS}

This too is important, since a clinician needs to be sufficiently certain of his diagnosis to take a decision in respect of treatment for the patient. We do not have any estimate of the clinicians' certainty levels, since we have preferred to study this aspect of the diagnostic process in a less exacting situation (to ask clinicians to pause and contemplate mathematics in an emergency situation was, we felt, unjustifiable at that time). However, for what it is worth, the mean certainty level for the eventual diagnosis in the 304 cases combined was $84.7 \%$ as regards the computing system. This implies that even when the system misclassified the patient, the eventual correct diagnosis was usually considered as the "next best" possibility. Furthermore, it should be recalled that we deliberately set up a routine in our diagnostic programme to deal with this difficulty (see Horrocks et al., 1972).

\section{Discussion}

Many workers have studied the possibility of aiding the clinician with some kind of Bayesian information-processing system in the field of clinical diagnosis (Lipkin and Hardy, 1958; Edwards, 1962, 1966; Lodwick, 1963; Lipkin, 1964; Collen et al., 1965; Kaplan and Newman, 1966; Philips et al., 1966; Lusted, 1968; Card, 1970; Taylor, 1970). Indeed, some of these workers have elegantly shown that the human is less effective than the computer in analysing the large volume of information contained in the conventional case history. To this extent there is nothing revolutionary in the present study.

We have been concerned with some rather different problems. Does the clinician actually need help? What are his strengths and weaknesses? Can the computer offer the type of 
help required? Can it offer any improvement in performance ? Can it do so in a routine clinical environment? To judge from our own studies, the answer to the latter two questions must be a qualified affirmative. The system was far from perfect, but (using identical information) it made significantly fewer errors than the clinical team-and lest this be thought a criticism of the clinicians concerned, no less an authority than Shepherd (1968), in what is probably the definitive textbook on the subject, cites his own diagnostic accuracy in this field as around $70 \%$, rather less than many of the clinicians we studied.

It must, however, be re-emphasized that we have not yet created a system of "computer diagnosis." What we have created is a system which can be used to help the clinician towards his own diagnosis, and which, if implemented, might well significantly improve the quality of the care which the clinician can give to his patient. We are far from unaware of the difficulties in implementation which face us, and it is to these additional problems that we have now turned our attention.

It is a pleasure to thank Professor J. C. Goligher for his encouragement and advice throughout this investigation; and to thank both Professor Goligher and Mr. D. Johnston for permission to study patients admitted under their care. We thank also the clinicians whose experience forms much of the basis of this report, both for taking part in this investigation and for allowing us to use their experience as a basis for comparison. Finally two of us (D. J. L. and J. C. H.) were aided by a grant from the Medical Research Council, which we also acknowledge with gratitude.

\section{References}

Card, W. (1970). Fournal of the Royal College of Physicians of London, 4, 183. Research, vol. 1, p. 339 . New York, Academic Press.

Edwards, $\mathbb{W}$. (1962). I.E.E.E. Transactions on Human Factors in Electronics, 4, 59 .

Edwards, W. (1966). I.E.E.E. Transactions on Human Factors in Electronics, 7,1 .

Horrocks, J. C., McCann, A. P., Staniland, J. R., Leaper, D. J., and de Dombal, F. T. (1972). British Medical fournal, $2,5$.

Kaplan, R. J., and Newman, J. R. (1966). I.E.E.E. Transactions on Human Factors in Electronics, 7, 49.

Lipkin, M. (1964). In The Diagnostic Process, ed. J. A. Jacquez, p. 255, Ann Arbor, Michigan, Malloy.

Lipkin, M., and Hardy, J. D. (1958). Fournal of the American Medical Association, 166, 113.

Lodick G. America, 3, 487.

Lusted, L. B., (1968). In Introduction to Medical Decision Making, p. 3. Springfi, (1llin). In Introducti

Springfield, Illinois, Thomas.
Philips, on Human Factors in Electronics, 7, 7 .

Shepherd, W. A. (1968). In Surgery of the Acute Abdomen, p. 32. Edinburgh,

Taylor, T. R. (1970). Fournal of the Royal College of Physicians of London, 4, 188.

\title{
Abnormal Glomerular Filtration Rate, Renal Plasma Flow, and Renal Protein Excretion in Recent and Short-term Diabetics
}

\author{
J. DITZEL， K. JUNKER
}

British Medical fournal, 1972, 2, 13-19

efferens leading to an increase in the filtration pressure. The increase in protein excretion rate may similarly be a consequence of this process or of an increase in the gloSummary

Glomerular filtration rate and renal plasma flow were simultaneously determined in comparable groups of $\mathbf{4 3}$ diabetics less than $\mathbf{4 0}$ years of age and with a duration of diabetes less than 10 years and 32 control subjects. The average glomerular filtration rate in the diabetic group was significantly higher than that in the control group $(P<0.01)$. The average renal plasma flow in the diabetic group was found to be significantly lower than that in the control group $(P<0.05)$. The filtration fraction in both male and female diabetics was significantly higher than in the male and female control groups $(P<0.001)$. These changes were found to be present even in recent juvenile diabetics with disease of a duration of less than one year. No correlation was apparent between the average levels of serum growth hormone and glomerular filtration rate.

The urinary protein excretion was determined in 36 diabetic and 38 healthy subjects comparable with regard to glomerular filtration rate. In the diabetic group there was a greater frequency of cases with higher protein excretion rates $(P<0.02)$. The average protein excretion rate was increased even in diabetics with less than one year's duration of the disease.

The results of the changes in renal haemodynamics in subjects with recent and short-term diabetes are compatible with the presence of a constrictive state of the vas merular permeability with augmented molecular sieving of proteins or both.

\section{Introduction}

It has now been well established, both by the classical inulin clearance and by the clearance of isotope-labelled substances $\left({ }^{57} \mathrm{Co}-\right.$ cyanocobalamin and ${ }^{51} \mathrm{Cr}$-edetic acid complex) that the glomerular filtration rate is increased in diabetics early in their disease compared with healthy persons of similar age and sex (Spühler, 1946; Stalder et al., 1960; Ditzel and Schwartz, 1967; Ditzel et al., 1972). The mechanism of this increase is not known, but three major possibilities exist either alone or in combination. It might be related to an increase in renal plasma flow owing to a dilatation of the vas afferens or to a decrease in renal plasma flow owing to a constriction of the vas efferens, leading to a higher filtration pressure in the glomerular capillaries, or it might be caused by an increased permeability of the glomerular apparatus per se and then possibly associated with an increased molecular sieving of proteins.

To elucidate these possibilities the present study relates glomerular filtration rate to other criteria of renal function and to simultaneous metabolic and endocrine changes in short-term diabetics.

\section{Subjects and Methods}

Simultaneous determinations of glomerular filtration rate and renal plasma flow were made in 75 individuals -43 diabetics 